\title{
ANALYSIS OF WORKING POSTURES WITH MUSCULOSKELETAL DISORDERS (MSDS) COMPLAINT OF TAILORS IN ULAK KERBAU BARU VILLAGE, OGAN ILIR
}

\author{
Betty Andriani, Anita Camelia, H.A Fickry Faisya \\ Faculty of Public Health, Sriwijaya University
}

\begin{abstract}
Tailor is one of the professions that has MSDs risk. It is because of the working posture, such as sitting for a long time and repetitive movements. The purpose of this study is to determine relationship between working postures and Musculoskeletal Disordes (MSDs) of Tailors in Ulak Kerbau Baru Village Ogan Ilir. This research was an cross-sectional and method of sampling in this study was using total sampling with sample were 75 respondents. Rapid Entire Body Assessment (REBA) method was used assessed the risk of working posture and questionnaires. Nordic Body Map was used determine of Musculoskeletal Disorders. The data is performed using univariate and bivariate with chi-square. Based on calculations used the REBA posture tailor working $42.7 \%$ of respondents has high risk and $57.3 \%$ has medium risk. Results of this analysis used statistical there were a significant relationship between age ( $p$-value $=0.006$ CI 1,730-25,281), working period ( $p$-value $=0.023$ CI 1,343-30,271), working posture (pvalue 0.027 CI 1,284-11,847), and the working time $(p$-value $=0.032$ CI 1,145-74,602) with Musculoskeletal Disorders (MSDs), and there was no significant relationhips between the sexes ( $p$-value $=0.610$ CI 0,224-1,898) with Musculoskeletal Disorders (MSDs). The majority of tailor work posture were at high risk, the researcher suggests to do intervention on modified factors, which are working postures and working time. Intervention can be done by using ergonomic work chair and make time to do stretch up (physical activity) every 30 minutes to reduce muscle fatigue.
\end{abstract}

Keywords: Working posture, musculoskeletal disorders (MSDs), tailors

\begin{abstract}
ABSTRAK
Penjahit merupakan salag satu profesi yang memiliki risiko MSDs. Penyebabnya karea postur kerja, seperti duduk untuk waktu yang lama dan gerakan berulang. Tujuan dari penelitian ini adalah untuk mengetahui hubungan antara postur kerja dan Musculoskeletal Disorders (MSDs) dari Penjahit di Ulak Kerbau Baru, Kabupaten Ogan Ilir. Penelitian ini merupakan penelitian cross-sectional dengan metode pengambilan sampel dalam penelitian ini menggunakan total sampling dengan sampel sebanyak 75 responden. Metode Rapid Whole Body Assesment (REBA) digunakan untuk menilai risiko postur kerja dan kuesioner. Nordic Body Map digunakan untuk menentukan gangguan Musculoskeletal. Data dilakukan dengan menggunakan univariat dan bivariat dengan chi square.Berdasarkan perhitungan REBA terdapat $42,7 \%$ pekerja dengan potensi high risk dan 57,3\% mendapatkan penilaian medium. Hasil analisis ini menggunakan statsitik terdapat hubungan yang signifikan antara usia $p$-value $=0.006 C I \quad 1,730-25,281)$, lama kerja $(p$-value $=$ 0.023 CI 1,343-30,271), postur kerja ( $p$-value 0.027 CI 1,284-11,847), dan waktu kerja $p$-value $=0.032 C I$ 1,145-74,602) dengan gangguan Musculoskeletal disorders (MSDs)Mayoritas postur kerja mendapatkan kategori high risk, peneliti menyarankan untuk melakukan intervensi pada faktor-faktor yang dimodifikasi, yaitu postur kerja dan waktu kerja. Intervensi dapat dilakukan dengan menggunakan kursi kerja yang ergonomis dan luangkan waktu untuk melakukan peregangan (aktivitas fisik) setiap 30 menit untuk mengurangi kelelahan otot.
\end{abstract}

Kata kunci: Postur kerja, musculoskeletal disorders (MSDs), penjahit 


\section{INTRODUCTION}

Musculoskeletal disorders (MSDs) are a symptom that occurs in muscles, nerves, tendons, ligaments, joints, cartilages, and intervertebral discs. These symptoms are caused by work carried out continuously and are chronic such as workload, static work posture, frequency and duration. ${ }^{1,2}$ MSDs is characterized by complaints such as pain, numbness, tingling, swelling, stiffness, trembling, sleep disturbance and burning sensation. ${ }^{13}$ The areas of the body most commonly involved are lower back, neck, forearm shoulders and hands. ${ }^{4}$ Musculoskeletal complaints are complaints that occur in parts of the skeletal muscle. ${ }^{26}$ Broadly speaking, muscle complaints can be grouped into two, namely temporary complaints (reversible) where complaint occurs when the muscle receives a static load and persistent complaints (irreversible) where even though the workload has been stopped, the pain in the muscle still continues. ${ }^{7}$

Every job has potential hazards and risks, both sourced from work activities, tools and materials used, and work environment. In addition to occupational safety and health hazards there are also ergonomic hazards that need attention. ${ }^{8}$ Ergonomic problems in the workplace are risk factors that contribute to the occurrence of work function disorders, especially MSDs. ${ }^{89}$ Recent studies in the United States show that MSDs represent 40 percent of injuries incurred in addition to annual costs of US \$ 45-54 billion. ${ }^{10}$ The global prevalence of MSDs ranges from $14 \%$ to $42 \% .{ }^{11}$ The issue of MSDs is very important as WHO stated in the decade of the 2000s to prevent the occurrence of MSDs. ${ }^{10} 12$

Work-Related Musculoskeletal Disorders (WMSDs) are most common in informal sector workers. Experts from across the Asia-Pacific region in Tokyo have warned that MSDs pose a major threat to productivity and economic growth in a variety of companies and industries. ${ }^{13} \mathrm{In}$ general, informal workers lack awareness and knowledge about the hazards in the work environment.Informal workers are not protected by law or legally because informal workers are not officially registered labors. ${ }^{714}$ The informal sector workers does not have health insurance and there is no compensation due to work accidents or occupational diseases. ${ }^{15} 16$

Sewing is a job where workers tend to sit for a long period of time. Workers of this type are primarily tailors who often experience a state of rigid posture, static muscle loads due to repetitive tasks and high work demands that cause the dependency to work while sitting becomes larger This group of workers often experience a state of rigid work postures and static muscle loads. ${ }^{715}$ Musculoskeletal Disorders (MSDs) are the most common occupational diseases in the process of sewing clothes. ${ }^{1718}$ Sewing work is the activity where both hands are always on the sewing machine table to hold the object of the stitching and both feet pressing the saddle powered dynamo, with their neck tilted forward. If this happens for a long time, this work can cause 
complaints of muscle pain in the shoulder area, neck stiffness, and back pain. ${ }^{51920}$ MSDs in tailors usually occur because the equipment used still does not meet ergonomic standards, long sitting postures with odd postures on the arms, neck, back and legs, repetitive movements, monotonous work, and erratic work hours. ${ }^{6} 1121$ The factors of the workers themselves are age, length of work and history of disease. While the work environment factors are vibration, temperature and lighting level. ${ }^{7} 122223$

This study aims to find out how the ergonomics risk of the tailor's garment industry work posture and the factors that influence it. The lack of data of informal workers, and ergonomic risk to tailors encourage researchers to further study the level of ergonomic risk in sewing work in the informal sector or home industry and what influences the risk level. ${ }^{813}{ }^{24}$ This study intends to raise the facts about the level of risk of ergonomics received by tailors. ${ }^{12526}$ Using the Rapid entire Body Assessment (REBA) method with a quantitative approach and calculating the prevalence of Musculosceletal Disoorders using the Nordic Body Map (NBM). ${ }^{25} 27$

\section{METHOD}

This study is using cross sectional design. In this study, researchers intend to raise the facts on the level of risk of ergonomics received by tailors by using the Rapid Entire Body Assessment (REBA) method with a quantitative approach and calculate the prevalence of Musculoskeletal Disorders by using the Nordic Body Map (NBM). ${ }^{28}$ This is then followed by a statistical analysis to analyze the relationship of factors that cause fatigue in musculoskeletal disorders. This research was carried out through 3 stages: initial survey, observation to assessment of work posture and statistical analysis.

Work posture data were analyzed descriptively with REBA Worksheet. The population in this study were all tailors in the village of Ulak Kerbau Baru, Ogan Ilir Regency, South Sumatra Province. Total sample is 75 tailors. Research variables are individual factors (age, sex, years of work) and work factors (work posture and working time). Data was collected through interviews using the NBM (Nordic Body Map) questionnaire ${ }^{29} 28$ and direct observation by photographing and taking videos of tailor activities. Then, researchers carried out an assessment of work posture ergonomic risk using the REBA (Rapid Entire Body Assessment) method. ${ }^{22} 2330$ Univariate and bivariate data was analysed with chi square test. 


\section{RESULTS}

Table. 1 Distribution Frequency of MSDs Complaints, Individual Factors and Work Factros in Tailors

\begin{tabular}{lcc}
\hline \multicolumn{1}{c}{ Variable } & n & \% \\
\hline MSDS Complaints & 19 & 25,3 \\
Severe complaint & 56 & 74,7 \\
Moderate Complaint & & \\
\hline Individual Factors & & \\
Age & 41 & 54,7 \\
$\geq 35$ & 34 & 45,3 \\
$<35$ & & \\
Gender & 49 & 65,3 \\
Female & 26 & 34,7 \\
Male & & \\
\hline Years of Work & 49 & 65,3 \\
$>4$ year & 26 & 34,7 \\
$\leq 4$ year & & \\
\hline Work Factors & & 44,0 \\
Work Posture & 33 & 56,0 \\
High Risk & 42 & 73,3 \\
Medium Risk & & 26,7 \\
\hline Time of Work & 55 & \\
\hline 4 hour/day & 20 & \\
$\leq 4$ hour/day & & \\
\hline
\end{tabular}

Based on table 1 it is known that all respondents felt MSDs complaints but tailors in Ulak Kerbau Baru Village felt the most complaints from MSDs with the percentage of 74.7\%. 54.7\% respondents aged $\geq 35$ years which is more than respondents aged $<35$ years and the majority of tailor workers are women, as many as $65.3 \%$ and $65.3 \%$ of tailors have a working period of $>4$ years. $73.3 \%$ of tailor's working time per day is $>4$ hours /day. The results of calculations using REBA to the risk of work posture is $56.0 \%$ of respondents have a work posture with moderate risk (REBA score 4-7) which means that further investigation and immediate change is needed.

The assessment of work posture using the REBA method divides 2 groups of body parts, namely group A (posture of the neck, back, legs) and group B (upper arms / shoulders, lower arms / elbows, wrists) by considering the weight lifted, grips and activities. The results of the occupational risk level is that the majority of tailor's work postures are at high risk, with a value of 8 . The lowest REBA score is 6 , it means it is included in the medium risk category and the largest REBA score of 10 , where it's included in the high risk category. 


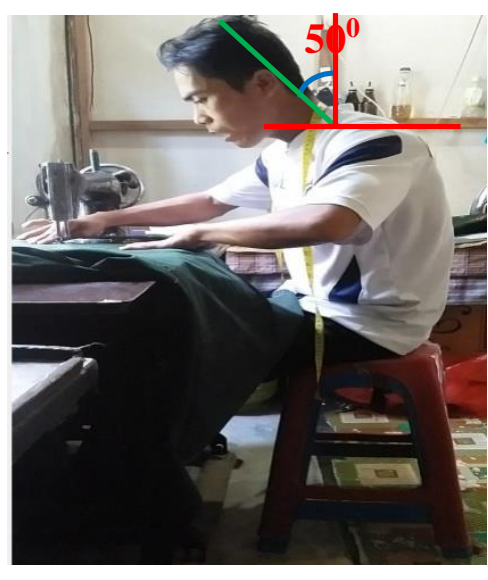

a.

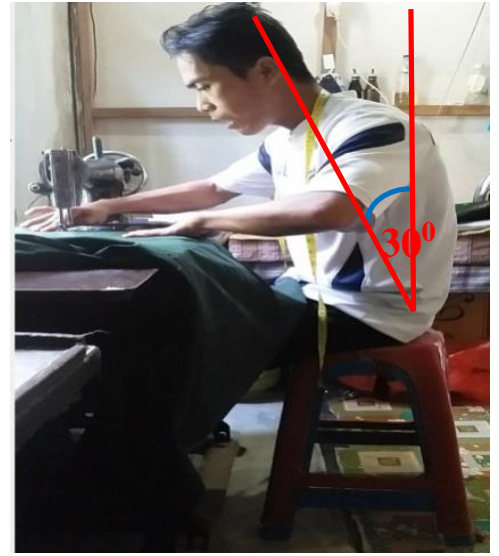

b.

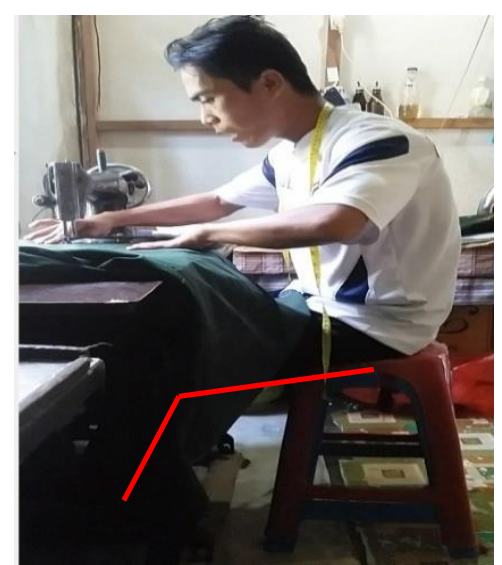

c.

\section{Picture. 1 Evaluation of REBA Group A to the Tailors of the Ulak Kerbau Baru} Village

Worker's neck posture in figure a. Is forming an angle of 500 where the position of the worker's neck is settled, not doing a circular motion or shaking his head. In accordance with the REBA assessment sheet, the tailor's neck posture gets a value of +2 . Tailor worker back posture in figure b. forming an angle of 300 which shows slight bending and no sideways movement. In accordance with the REBA assessment sheet back posture with an angle of 20-600 is rated +3 . Leg posture in the picture c. rated +1 because the worker works in a seated position where the workers' legs shake the sewing machine. The body rests on both feet and is in a balanced state.

To get the group A score, an object weight load value is added. The weight of the sewing work object is obtained from the neck posture which forms an angle of more than 200 with a fixed or static position equal to holding a 15-pound head load then the object load is equal to +2 so the score for group A is determined to be 6 .

Posture of the upper arm of the tailor worker in the picture d. below, forms an angle of 650 so that when viewed from the REBA assessment sheet for the upper arm posture that forms an angle of 45-900 is given a value of +3 . Tailor forearm posture in figure e. forming an angle of 1500 , so based on the REBA assessment sheet a value of +2 is given. Wrist posture in figure $f$. forming an angle of 200 so that it gets a value of +2 . The right hand wrist sometimes turns the wheel so the sewing machine runs so that it adds $a+1$ value. So the score of the right wrist is +3 . After obtaining a value for each posture then enter it into table B and to get a score of group B is done by adding the value of the hand grip. When sewing the position of the handle is good enough to support the hand so that based on the REBA assessment sheet there is no need to get additional grades. Then for group B get a score of 5 . 


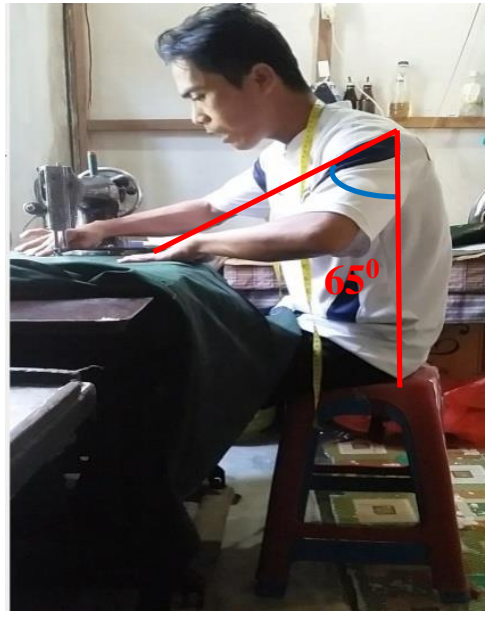

d.

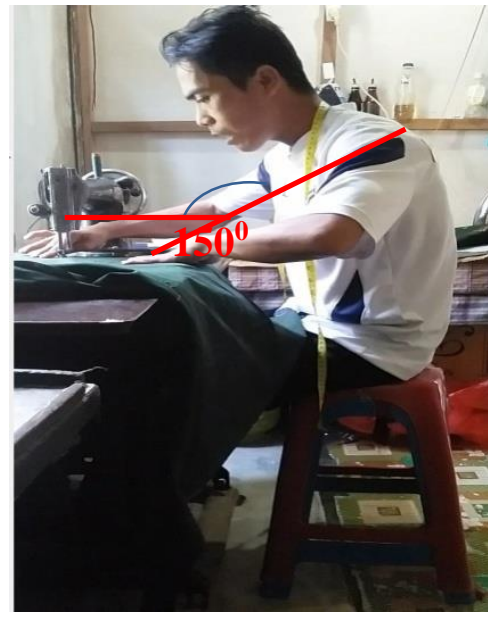

e.

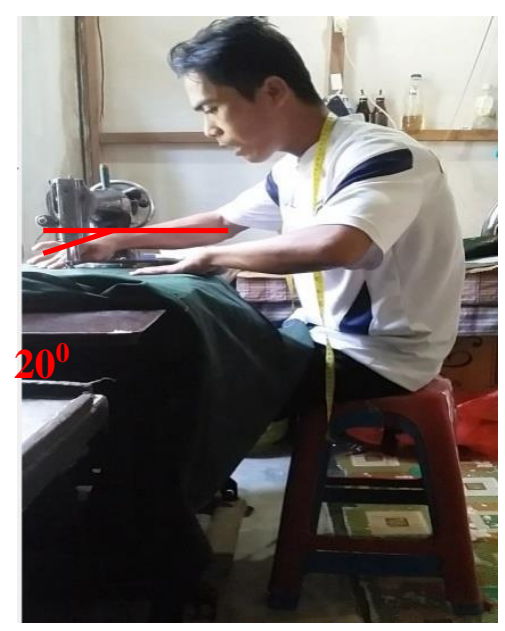

f.

Picture. 2

\section{REBA Evaluation for Group B in the Ulak Kerbau Baru Village Tailor}

After getting scores A and B then enter each score into table C. To get the final score from the sewing work posture, add the activity value. The sewing work is carried out in a fixed or static body position for more than 1 minute, so based on the REBA assessment sheet a value of +1 is given. Sewing activities also provide repetition of movements in the hands and feet. This activity is repeated more than 4 times in 1 minute so as to get an additional value of +1 , then the value of activities in sewing work is 2 .

The final score is the result of the $\mathrm{C}$ table score plus the activity score so that a REBA score of 10 is achieved. This score indicates that sewing work has a high level of risk that an investigation must be carried out immediately and a change in the position of the work posture is needed.

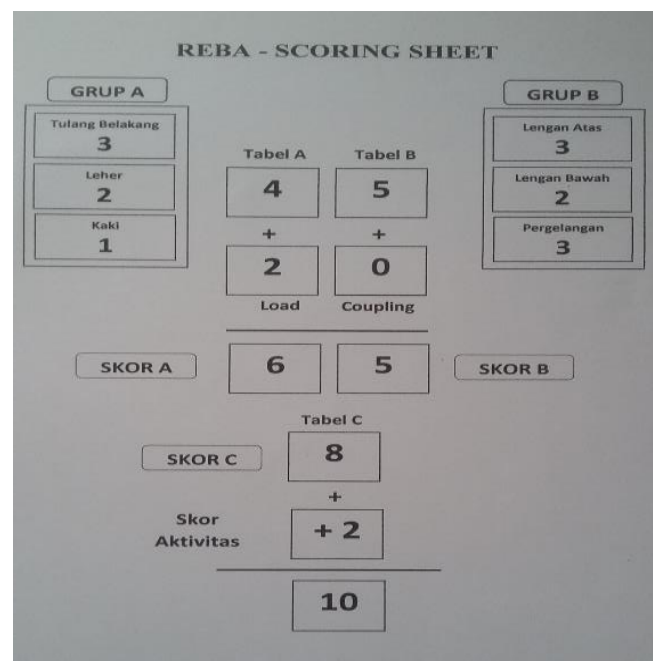

Picture. 3 Example of Score Calculation Using REBA 
Table. 2 Relationship Between Individual Factors and Occupational Factors with Complaints MSDs

\begin{tabular}{|c|c|c|c|c|c|c|c|}
\hline \multirow{3}{*}{ Variable } & \multicolumn{4}{|c|}{ Complaints MSDs } & \multirow{3}{*}{$\mathbf{n}$} & \multirow{3}{*}{$P$-value } & \multirow{3}{*}{$\begin{array}{c}\text { PR } \\
(95 \% \mathrm{CI})\end{array}$} \\
\hline & \multicolumn{2}{|c|}{ Serve } & \multicolumn{2}{|c|}{ Moderate } & & & \\
\hline & $\mathbf{n}$ & $\%$ & $\mathbf{n}$ & $\%$ & & & \\
\hline \multicolumn{7}{|l|}{ Age } & \multirow{3}{*}{$\begin{array}{c}6,613 \\
1,730-25,281\end{array}$} \\
\hline$\geq 35$ Year & 16 & 39,0 & 25 & 61,0 & 41 & 0,006 & \\
\hline$<35$ Year & 3 & 8,8 & 31 & 91,2 & 34 & & \\
\hline \multicolumn{7}{|l|}{ Gender } & \multirow{3}{*}{$\begin{array}{c}0,651 \\
0,224-1,898\end{array}$} \\
\hline Female & 11 & 22,4 & 38 & 77,6 & 49 & 0,610 & \\
\hline Male & 8 & 30,8 & 18 & 69,2 & 26 & & \\
\hline \multicolumn{7}{|l|}{ Years of Work } & \multirow{3}{*}{$\begin{array}{c}6,375 \\
1,343-30,271\end{array}$} \\
\hline$>4$ Year & 17 & 34,7 & 32 & 65,3 & 49 & 0,023 & \\
\hline$>4$ Year & 2 & 7,7 & 24 & 92,3 & 26 & & \\
\hline \multicolumn{7}{|l|}{ Work Posture } & \multirow{3}{*}{$\begin{array}{c}3,900 \\
1,284-11,847\end{array}$} \\
\hline High Risk & 13 & 39,4 & 20 & 60,6 & 33 & 0,027 & \\
\hline Medium Risk & 6 & 14,3 & 36 & 85,7 & 42 & & \\
\hline \multicolumn{7}{|l|}{ Time of Work } & \multirow{3}{*}{$\begin{array}{c}9,243 \\
1,145-74,602\end{array}$} \\
\hline$>4$ hour & 18 & 32,7 & 37 & 67,3 & 55 & 0,032 & \\
\hline$\leq 4$ hour & 1 & 5 & 19 & 95 & 20 & & \\
\hline
\end{tabular}

The bivariate analysis in table. 2 above shows that there are four variables that have a statistically significant relationship, namely age (p-value 0.006 ), years of working ( $p$-value 0.023 ), work posture (p-value 0.027), and work time ( $\mathrm{p}$ - value value 0.032 ).

\section{DISCUSSION}

The results of the study and interviews was using the NBM questionnaire which was conducted on 75 tailors. The results ontained is $25.3 \%$ of respondents experiencing severe MSDs complaints and $74.7 \%$ of respondents experiencing moderate MSDs complaints. The most frequent complaints felt by tailors are pain and aches while the body parts that often experience pain and aches are the waist area $65.33 \%$, hips $50.67 \%$, back $48 \%$, and upper neck $46.67 \%$. The frequency of complaints appear almost every day at work and after work.

Musculoskeletal complaints are complaints that are felt by a person ranging from minor to complaints that are very painful in the skeletal muscle parts. ${ }^{29}$ If the muscle receives a static load repeatedly for a long period of time, it will cause complaints in the form of damage to the joints, ligaments and tendons. ${ }^{14} 31$ Complaints to this damage are called injuries to the musculoskeletal system or musculoskeletal disorders (MSDs). ${ }^{32}$ Complaints in the musculoskeletal region are occupational diseases caused by the lack of or no application of ergonomic principles. ${ }^{2} 1833$

The age of the respondent is related to MSDs complaints. The results of the study are in accordance with Tarwaka's theory which says that skeletal muscle complaints begin to be felt at the age of 25-65 years but generally the first complaint is felt at age 35 years and the level of complaints will continue to increase with age because in middle age, muscular strength and endurance begins to decrease so the risk of muscle complaints will increase. ${ }^{29}$ This study is also in line with research conducted ${ }^{3}$ that there is a relationship between age and MSDs in Furniture in 
Leilem Dua Village, Sonder District. Respondents in the age range of 30-59 years experienced $100 \%$ complaints of MSDs

The increase of age causes a person's physical condition to be weaken and the possibility of them making mistakes when working is getting higher, so it will have an impact on the decrease of work quality. The existence of these errors can cause work related illness, which in this case is a musculoskeletal complaint. ${ }^{23} 34$ Based on field observations in tailors it turns out that tailors aged $<35$ years experience more MSDs complaints, this can be caused by the length of time the tailors work because the longer a person works with these MSDs risk factors, the greater the risk of experiencing MSDs. It is known that $30 \%$ of tailors aged $<35$ years have worked more than or equal as 4 years. Thus to reduce the risk of MSDs complaints, tailors are expected to pay more attention to their physical conditions, one of them is by exercising especially for tailors over the age of 35 years because of increasing age one's physical strength will decrease.

The results showed that there was no significant relationship between sex and MSDs complaints. Research from various workplaces shows that the prevalence of musculoskeletal pain is higher for women than men in the general population aged 25 to 64 years. Musculoskeletal pain complaints occur in $39 \%$ of men and $45 \%$ of women where they reported chronic complaints. The highest complaints on female was found for the hips and wrists. ${ }^{35}$

When working, women are more vulnerable to illness than men. As many as $42 \%$ of women have the risk of experiencing MSDs complaints while working. This can be caused by a decrease in the hormones estrogen and progesterone which functions is to maintain muscle and 7 ligaments suppleness so that they are able to withstand excessive workload. ${ }^{35}$ Decreased estrogen and progesterone hormones can be caused by many things, such as caring for children women who are breastfeeding and, women who have experienced menopause and women who takes care of the household snd their stress triggered by it. ${ }^{36}$

There is no relationship between sex with MSDs complaints based on the researchers' assumptions because the percentage of female workers is greater than that of men so this results has an uneven distribution. Facts on the field show that female tailors over the age of 35 are more numerous than men. In addition, the number of years of work and the number of hours of work per day in women is more than men. To fulfill the necessities of life other than sewing, male tailors also have a side job which is farming or gardening while women also do house chores aside from sewing.

In this study, work length has a significant relationship with complaints of MSDs and tailors with a service of $>4$ years have a risk to experience severe MSDs 6.375 times greater than tailors with lower work length. The results of research conducted by workers who have a working period of more than 4 years have a risk of 2.755 times larger compared to workers with a service period of $\leq 4$ years. ${ }^{37}$ In relation to this, MSDs are chronic diseases that take a long time to develop and 
manifest. So, the longer the working time or the longer a person is exposed to these MSDs risk factors, the greater the risk of experiencing MSDs. ${ }^{18}$

The majority of tailors' work length in Desa Ulak Kerbau Baru with $>4$ years is more than the work period of $\leq 4$ years which is $65.3 \%$. The average length of work of a tailor in Desa Ulak Kerbau Baru is 10 years, with the longest is 23 years and the shortest is 1 year. Most of the tailors who have worked for more than 7 years claimed to have started sewing since completing the highschool (SMA). Before working as a tailor, there were several respondents who traded, farmed and were housewives. Seeing the rapid development of sewing and profits obtained are deemed sufficient to meet the needs of life became the reason respondents switching professions to be a tailor. The Ulak Kerbau Baru Village tailors have never had a holiday, they are on leave only if it's really urgent.

The results of this study indicate that there is a significant relationship between work posture and MSDs complaints. This is in line with a study where that results show that there is a relationship between work attitudes and MSDs complaints on tailors in the center of Menteng Small Industries in 2015 with a p-value of $0.015 .{ }^{18}$ Sewing is done with static postures and repetitive postures. When the body is in a static position, there will be a blockage in the blood flow and results in a lack of oxygen and glucose from the blood. In addition, the body will produce metabolic waste such as lactic acid that cannot be transported out due to disrupted blood circulation which builds up and causes pain. ${ }^{36}$

Based on field observations on tailors in Desa Ulak Kerbau Baru, there was a mismatch between work designs and workers which resulted in the work posture being not ergonomic. The work design mismatch is proved by the design of the chair used by tailors while working and makes workers feel the most complaints MSDs on the above of their waist (68\%), upper neck and back $(45.3 \%)$ and lower neck (44\%). The majority of chairs used by tailors are wooden chairs that does not have a back rest, seat cushion and the chair height can not be adjusted. This of course results in an odd work position which causes parts of the body to move away from the body's natural position. If working conditions like this occur in a long time, it will cause injury to the muscles, especially in the upper body such as the neck, back, shoulders and waist.

To make the tailor feel more comfortable working, they should replace their chair that does not have a backrest, cushion holder and seat height that cannot be adjusted with a chair that has a backrest, cushion holder and a seat that can be adjusted in height. Another alternative to overcome fatigue, nervousness in the muscles during sitting that will later have an impact on MSDs complaints is by standing up from sitting position every 30 minutes and walking for 5 minutes then stretching the muscles that experience tension. Besides not requiring costs, this can also reduce tension in the muscles so workers feel more relaxed. 
Statistical test results show that there is a significant relationship between the time spent with MSDs complaints. Working time of more than 4 hours has 9,243 times greater risk of experiencing MSDs compared to workers who have work times less than 4 hours. This study is in line with Arwino's research on Garment tailors showing a relationship between the length of work time and joint muscle complaints with $\mathrm{p}$ value $0.006 .{ }^{5}$ Sewing is work that is done in a sitting situation and with continuous repeated activities. According to Samara et al. Jobs such as sewing greatly affect subjective complaints of pain in the back, neck and waist. ${ }^{38}$

Tailors in Ulak Kerbau Baru Village, on average, start sewing from 08.00 to 17.00 West Indonesia Time with 1-2 hours rest period, starting again from 12.00 until 14.00 West Indonesia Time. The average work time per day tailor Ulak Kerbau Village is 7 hours, with shortest work duration is at least 2 hours and a maximum of 12 hours. Tailors who do work for 2 hours per day is due to their status as a student so that sewing is done when returning from school. While some tailors work for 12 hours due to many orders and chasing their deadline so that the stitches are completed on time. During breaks other than rest, prayer and eat, female tailors usually do household chores such as cooking, washing dishes, sweeping and caring for children. Whereas male tailors usually use time off to eat, pray, and sleep.

Sewing work that is done by sitting for too long can cause excessive boredom. This excessive boredom arises because of the static body position and excessive monotony of boredom can also cause muscle fatigue and stress. To avoid this, it is recommended for tailors to stand up or do light activities every 30 minutes to relax your body from stiffness.

\section{CONCLUSION}

Based on the results of research on tailors in Desa Ulak Kerbau Baru, it can be concluded that there is a relationship between work posture and MSDs complaints. 74.7\% Tailors in the village of Ulak Kerbau Baru experienced moderate MDS complaints. The waist is the most complained part of the body experiencing MSDs which amounts to $68 \%$ complaints. Respondent characteristics showed that $54.7 \%$ of tailors were older than 35 years, $65.3 \%$ were female, $73.3 \%$ had more than 4 hours of work per day, $65.3 \%$ had more than 4 years of experience as tailor, and $57.3 \%$ have medium work posture risk. Age, working time, working years, and work posture are risk factors for MSDs complaints to tailors in Ulak Kerbau Baru Village.

The results of the measurement of work posture using the REBA method is that the majority of tailor's work postures are at high risk with a value of 8 , while the lowest REBA score is 6 which means it is included in the medium risk category and the largest REBA score of 10 is included in the high risk category. The most frequent complaints felt by tailors are pain and aches and body parts that often experience these complaints are their waist, hips, back, and upper neck. 
Suggestion from this research is that it is expected that tailor workers with age above 35 years should do physical activities such as exercising to minimize MSDs complaints, to prevent muscle tension, they should take a break every 20-30 minutes and stand to straighten their back several times and hopefully tailors can replace their working chairs with an ergonomic chair. If a seat change is not possible, then cushion should be added on the pedestal base and back of the chair. This can be used by workers to lean when they feel tired.

\section{REFERENCES}

1. Devi T, Purba IG, Lestari M. Faktor Risiko Keluhan Musculoskeletal Disorders (MSDs) Pada Aktivitas Pengangkutan Beras di PT Buyung Poetra Pangan Pegayut Ogan Ilir. J Ilmu Kesehat Masy [Internet]. 2017;8(2):125-34. Available from: http://www.jikm.unsri.ac.id/index.php/jikm

2. Wiranto A, Ramdan IM, Lusiana D. Faktor Yang Mempengaruhi Keluhan Musculoskeletal Disorder Pada Pekerja Penggilingan Padi Kabupaten Penajam Paser Utara. Husada Mahakam J Kesehat. 2019;4(8):439.

3. Tambuwun JH, Malonda NSH, Kawatu PAT. Hubungan Antara Usia dan Masa Kerja dengan Keluhan Muskulo-skeletal pada Pekerja Mebel di Desa Leilem Dua Kecamatan Sonder. Med Scope J. 2020;1(2):1-6.

4. Rachmat N, Utomo PC, Sambada ER, Andyarini EN. Hubungan Lama Duduk dan Sikap Duduk terhadap Keluhan Nyeri Punggung Bawah pada Penjahit Rumahan Di Kecamatan Tasikmadu. J Heal Sci Prev. 2019;3(2):79-85.

5. Arwino LD. Keluhan Nyeri Punggung Bawah pada Penjahit Garmen. Higeia J Public Heal Res Dev. 2018;2(3):407.

6. Dwivedi P, Kiran U V. Musculoskeletal Discomfort among Tailors". IOSR J Humanit Soc Sci (IOSR-JHSS [Internet]. 2016;21(4):10-2. Available from: www.iosrjournals.org

7. Wulandari DR, Moelyaningrum AD, Ragil Ismi Hartanti. Risiko Ergonomi Dan Keluhan Muskuloskeletaldisorders Pada Pekerja Jahit (Studi Di Ud. Ilfa Jaya Konveksi Banyuwangi - Indonesia). 2017;119-29. Available from: http://repository.unej.ac.id/bitstream/handle/123456789/75992/Dian_ Pratiwi $132310101064-1 . p d f$ ?sequence $=1$

8. Hendro H, Imdam IA, Karina RI. Usulan Perancangan Fasilitas Kerja Dengan Pendekatan Ergonomi Menggunakan Metode Rapid Entire Body Assessmnet (Reba) Di Pt Z. J Ind Res (Jurnal Ris Ind. 2016;10(1):1-11.

9. Upasana, Vinay D. Ergonomic Assessment Of Work Pattern And Related Musculoskeletal Discomfort Among Tailors. Int J Sci Environ Technol. 2019;8(4):867-73. 
10. Laal F, Mirzaei R, Behdani MS, Mohammadi M, Khodami K. Evaluation of the influence of ergonomic intervention on the musculoskeletal disorders of Zahedan tailors. Int J Occup Saf Ergon [Internet]. 2017;23(3):380-5. Available from: http://dx.doi.org/10803548.2016.1233674

11. Öztürk N, Esin MN. Investigation of musculoskeletal symptoms and ergonomic risk factors among female sewing machine operators in Turkey. Int $\mathrm{J}$ Ind Ergon [Internet]. 2011;41(6):585-91. Available from: http://dx.doi.org/10.1016/j.ergon.2011.07.001

12. Banerjee S, Bandyopadhyay L, Dasgupta A, Paul B, Chattopadhyay O. Work related musculoskeletal morbidity among tailors: A cross sectional study in a slum of Kolkata. Kathmandu Univ Med J. 2016;14(56):305-10.

13. Tambun MSMOSS. Penggunaan Metode Reba Untuk Mengetahui Keluhan Musculoskeletal Disorder Pada Pekerja Sektor Informal. J JIEOM Vol 02, No02, Novemb 2019 ISSN 26208184. 2019;02(02):5-7.

14. Hendrawan MB, Sutajaya IM, Citrawathi DM. Mekanisme kerja borongan yang monoton dan repetitif meningkatkan keluhan muskuloskeletal dan kelelahan penenun di Desa Gelgel Klungkung. J Pendidik Biol Undiksha [Internet]. 2019;6(1). Available from: https://ejournal.undiksha.ac.id/index.php/JJPB/index\%0AMEKANISME

15. M.A. MI, Sabilu Y, Pratiwi AD. Faktor Yang Berhubungan Dengan Keluhan Musculoskeletal Disorders (MSDs) Pada Penjahit Wilayah Pasar Panjang Kota Kendari Tahun 2016. Fakt Yang Berhubungan Dengan Keluhan Musculoskelet Disord Pada Penjahit Wil Pasar Panjang Kota Kendari Tahun 2016 Muhammad. 2016;1(2):1-8.

16. Dewi LT. Karakterisasi Keluhan Muskuloskeletal Akibat Postur Kerja Buruk Pada Pekerja Industri Kecil Makanan. J Ilm Tek Ind. 2017;15(2):145.

17. Odi KD, Purimahua SL, Ruliati LP. Hubungan Sikap Kerja, Pencahayaan Dan Suhu Terhadap Kelelahan Kerja Dan Kelelahan Mata Pada Penjahit Di Kampung Solor Kupang 2017. Ikesma. 2018;14(1):65.

18. Sihombing AP, Kalsum, Sinaga MM. Correlation between working posture and musculoskeletal disorders on tailors in Menteng small industry centre, Medan (in Indonesian). Lingkung dan Kesehat Kerja [Internet]. 2015;4(2):203-8. Available from: https://jurnal.usu.ac.id/index.php/lkk/article/view/10791

19. Jamro SA, Asif Sheikh M, Islam Rajput H, Baig Chughtai MJ. Work-Related Musculoskeletal Disorders Among Tailors. Int J Pharm Sci Heal Care. 2018;2(8):18-25.

20. Akodu A, Tella B, Adebisi O. Prevalence, Pattern and Impact of Musculoskeletal Disorders among Sewing Machine Operators in Surulere Local Government Area of Lagos State, Nigeria. Indian J Physiother Occup Ther - An Int J. 2013;7(2):15.

21. Kazemi S, Asgari A, Khatib M, Poyafar L, Mohammadi M. Determining the Prevalence of 
Musculoskeletal Disorders in Tailors in Kermanshah, Iran Using the Nordic Questionnaire (2018). Int J Heal Life Sci. 2019;In Press(In Press):1-4.

22. Upasana, Vinay D. Work Posture Assessment of Tailors By RULA and REBA Analysis. Int J Sci Environ Technol [Internet]. 2017;6(4):2469-74. Available from: http://www.ijset.net/journal/1849.pdf

23. Riningrum H, Widowati E. Pengaruh Sikap Kerja, Usia, dan Masa Kerja Terhadap Keluhan Low Back Pain. J Pena Med. 2016;6(2):91-102.

24. Livandy V, Setiadi TH. Prevalensi Gangguan Muskuloskeletal pada Pekerja Konfeksi Bagian Penjahitan di Kecamatan Pademangan Jakarta Utara periode Januari 2016. Tarumanagara Med J. 2018;1(1):183-91.

25. Ravisankar PIA, Year I. To Estimate the Prevalence of Work Related Musculoskeletal Morbidity amongst Tailors: A Cross Sectional Study in a Rural Area of Tamilnadu. 2019;4(11):484-8.

26. Restuputri DP, Lukman M, Wibisono. Metode REBA Untuk Pencegahan Musculoskeletal Disorder Tenaga Kerja. J Tek Ind. 2017;18(1):19.

27. Pujasakti MS, Widjasena B, Kurniawan B. Hubungan postur kerja dengan metode Quick Exposure Checklist (QEC) pada keluhan nyeri leher (Studi Kasus Pada Pekerja Operator Jahit BerdiriPT. MAS Sumbiri, Boja Kabupaten Kendal). J Kesehat Masy Vol 7, Nomor 4, Oktober 2019 (ISSN 2356-3346) [Internet]. 2019;7(4). Available from: http://ejournal3.undip.ac.id/index.php/jkm\%0Aberpotensi

28. Dani Ramdhani PMZ. Analisis Postur Kerja Pengrajin Handycraft Menggunakan Nordic Body Map Dan Metode Rapid Upper Limb Assessment (RULA). 2012;1-13.

29. Sudiajeng L. Ergonomi Untuk Keselamatan Kesehatan Kerja dan Produktivitas.

30. Restuputri DP, Dewi SK. Analisis Postur Tubuh Pekerja Minuman Sari Buah Menggunakan Metode OWAS dan REBA. J Teknol dan Manaj Agroindustri. 2018;7(1):1-11.

31. Utami U, Karimuna SR, Jufri N. Hubungan Lama Kerja, Sikap Kerja Dan Beban Kerja Dengan Muskuloskeletal Disorders (Msds) Pada Petani Padi Di Desa Ahuhu Kecamatan Meluhu Kabupaten Konawe Tahun 2017. 2017;2(6):1-10.

32. Pratama DN. Identifikasi Risiko Musculoskeletal Disorders(Msds) Pada Pekerja Pandai Besi. Indones J Occup Saf Heal. 2017;6(1):78.

33. Dita Puspita, Suroto BK. Analisis postur kerja terhadap keluhan muskuloskeletal disorders (MSDs) pada pekerja mekanik bengkel sepeda motor X Semarang. 2017;5(5):126-33.

34. Hadyan Mf. Hubungan Usia, Lama Kerja, Masa Kerja Dan Indeks Massa Tubuh (Imt) Terhadap Kejadian Low Back Pain (Lbp) Pada Petani Di Desa Munca Kabupaten Pesawaran. 2015;23:748.

35. K MAPN, Putu N, Yanti N, Kurniawan E, Artha Pw. Muskuloskeletal Pada Mahasiswa 
Universitas Udayana Tahun 2016 Factors Related Musculoskeletal Disorders On Students Of Udayana University On 2016 berbagai bentuk cedera, nyeri atau kelainan diderita yang. $2017 ; 1(2)$.

36. Akoul MA, AL-Jowari SAK. Comparative anatomical and histological study of some organs in two fish species Cyprinus carpio Linnaeus, 1758 and Mesopotamichthys sharpeyi (Günther, 1874)(Cypriniformes, Cyprinidae). Bull Iraq Nat Hist Museum. 2019;15(4):42541.

37. Sulung N. Beban angkut, posisi angkut, masa kerja dan umur dengan keluhan muskuloskeletal pada pekerja bongkar muat. 2016;1(June):63-74.

38. Astutik S, Sugiharto. Hubungan Antara Desain Kursi Kerja Dengan Keluhan Nyeri Punggung Bawah Pada Pekerja Bagian Penenunan Di Cv. Pirsa Art Pekalongan. 2015;4(1):61-8. 